\title{
Den gode vilje
}

\section{Om planlægningen og realiseringen af Agerskov-hallen}

\author{
af GunNar Lind HAASE SVENDSEN
}

I 1970'erne blev der bygget idrætshaller over hele landet. De ligger i småbyerne som udtryk for datidens stærke idrætsbevægelse. Agerskov fik sin idrætshal i 1974. I artiklen her fortæller antropologen Gunnar Lind Haase Svendsen om hallen i Agerskov. Den giver et eksempel på typiske forhold i en del landdistrikter på den tid: et bredt, frivilligt lokalt engagement og protest mod kommunale centraliseringstendenser. På længere sigt blev hallen dog helt afhængig af kommunal støtte.

\section{Indledning}

1960'ernes og 1970'ernes halbyggerier skal i vid udstrækning ses som resultat af en ny tendens i den danske ungdomsbevægelse efter Anden Verdenskrig. Hvor ungdomsforeningerne på landet tidligere havde søgt at forene ånds- og kropskultur, primært ved at forene foredrags- og oplysningsvirksomhed med gymnastikundervisning, blev det i løbet af 1950'erne kropskulturen og hermed idrætsforeningerne, der blev altdominerende.

Eftersom man i 1960'erne og 1970'erne ikke mente, de gamle og ofte misligholdte forsamlingshuse kunne rumme alle de nye idrætsaktiviteter, gav man sig i kast med at planlægge nye samlingssteder i form af kulturelle fællesbygninger, fritids- og kulturcentre, idrætsog svømmehaller - alle hovedsagelig med det formål at opfylde idrætsforeningernes stadigt stigende lokalebehov. ${ }^{1}$

Som tilblivelsen af Agerskov-hallen i høj grad vidner om, var der dog ikke blot tale om et generelt ønske om idrætsfaciliteter, eller som man sagde: et 'sted at være'. Efter kommunesammenlægningerne synes der endvidere at være opstået en ny selvbevidsthed $i$ de enkelte landdistriktssamfund, en ny sognebevidsthed så at sige.

Planlægningen og opførelsen af Agerskov-hallen i 1972-74 forekommer at være ganske repræsentativt for de talrige halbyggerier $\mathrm{i}$ 
de danske landdistrikter i 1970'ernes sidste halvdel. Herom vidner bl.a. artikler om lignende halbyggerier i De danske Gymnastik- og Ungdomsforeningers tidsskrift Dansk Ungdom og Idræt gennem perioden. ${ }^{2}$ I denne artikel vil planlægningen, opførelsen og driften af Agerskov-hallen derfor blive nøjere beskrevet med henblik på at give et illustrativt eksempel på »idrætshalsbevægelsen « i 1960'erne og 1970 'erne - en tydelig slægtning til "forsamlingshusbevægelsen « efter 1864.

Initiativtageren bag Agerskov-hallen, skoleinspektør ved Agerskov skole Hans-Jørgen Thomsen, fortæller, at ideen til hallen opstod i 1970-71 i forbindelse med en manglende støtte fra den nye centerkommune til opforelsen af en gymnastikhal nummer to i tilknytning til skolen. ${ }^{3}$ En del af skolen samt en gymnastiksal var blevet opført i 1968, men - trods et stort behov for endnu en gymnastiksal - fik man efter 1970 ikke grønt lys for at fortsætte byggeriet af en sal eller evt. en hal. "Hvad skal de med en hal i Agerskov?" synes stemningen ifølge Thomsen at have været $i$ den nye centerby Toftlund, hvor man allerede 2. oktober 1965 havde indviet Toftlundhallen. "Vi følte, vi blev forfordelt «, beretter Thomsen, der dengang var lærer på Agerskov skole og formand for Agerskov Ungdomsforening.

Imidlertid samledes indenfor ungdomsforeningen i begyndelsen af 1970 'erne en kreds, der ønskede at vise kommunen, at man ikke havde til hensigt blot at sidde og vente med hænderne i skødet.

\section{Foreningsildsjælene bag hallen}

Hvem var de folk, der ønskede at bygge en hal, og hvorfor lagde de så megen energi i det?

Som allerede nævnt var det lærer Hans-Jørgen Thomsen, der som formand for Ungdomsforeningen blev den store initiativtager. Thomsen, der er født og opvokset i Øsby ved Haderslev, fortæller, at han sammen med sin hustru flyttede til Agerskov i slutningen af 1960'erne i forbindelse med sin ansættelse på skolen. På det tidspunkt var der mange dynamiske, yngre folk, der flyttede til byen. Thomsen beretter herom:

Der kom mange tilflyttere, især fra Esbjerg-området. Flere blev ansat $i$ Elforsyningsselskabet, i Banken - der var også mange håndværkere, en overgang var der 11 murere. Mange byggede hus, og der var mange 
rejsegilder (...) Der var et stort sammenhold [mellem tilflytterne], alle kendte hinanden. Der skete noget ...

Gennem sidste halvdel af 1960 'erne var idrætsaktiviteterne vokset i Agerskov Ungdomsforening, ligesom det i ovrigt var tilfældet $i$ idrætsforeningerne i Bevtoft og Toftlund. Der blev især spillet fodbold, håndbold, samt dyrket gymnastik. Også resultatmæssigt opnåede de tre idrætsforeninger gode resultater omkring $1970 .^{4}$

Både Thomsen og to andre tilflyttede lærere, Christian Povlsen og Tage Hedegård Christensen, var meget aktive indenfor idrætsforeningerne i Agerskov Ungdomsforening. Især Hans-Jørgen Thomsen og kollegaen på Agerskov skole, Christian Povlsen, havde i det hele taget i perioden 1970-74 været meget dynamiske foreningsildsjæle i Agerskov og omegn. De var begge uddannet premierlejtnanter ved samme kaserne og kendte således hinanden på forhånd. Af de lokale mødte de "megen medspil« og til tider også »modspil«, fortæller Thomsen. I interviewene med Hans-Jørgen Thomsen i Vestkysten omkring årsskiftet 1971-72 støder man flere gange på udtalelsen: „Formålet er at sætte noget i gang «. 5

\section{Lokalbefolkningens ønske om et nyt samlingssted}

Gennem længere tid havde der været akut behov for idrætsfaciliteter i en by, der ikke havde haft eget forsamlingshus siden 1920'erne, omend nok en kro der kunne rumme mange ikke-idrætslige aktiviteter. $\mathrm{Nu}$ var det på tide, man fik et nyt samlingssted, mente Thomsen ...

Agerskov-hallen er ikke kun en idrætsplads. Den er det samlingssted eller forsamlingshus - som vor tids mennesker onsker og har brug for (...) Vor tids mennesker har ønsker, de har stærke meninger, og de har travlt, de bør, skal og vil mange ting, og al den aktivitet og vilje præger det samfund, vi bor og lever i. $^{6}$

I en artikel fra 17. januar 1973 "Selvfølgelig skal Agerskov ha' en hal «, der byggede på en "rundspørge, vi [Vestkystens journalister] har foretaget blandt tilfældig valgte borgere, vi traf under et besøg i Agerskov«, syntes argumentet om de manglende lokale faciliteter også at veje tungt. Således udtalte husmoder fru M. Klingenberg, at hun troede, "det vil gavne hele Agerskov, at vi får et sted, hvor både unge og ældre kan samles“, tobakshandler Chr. Dethlefsen betonede nød- 


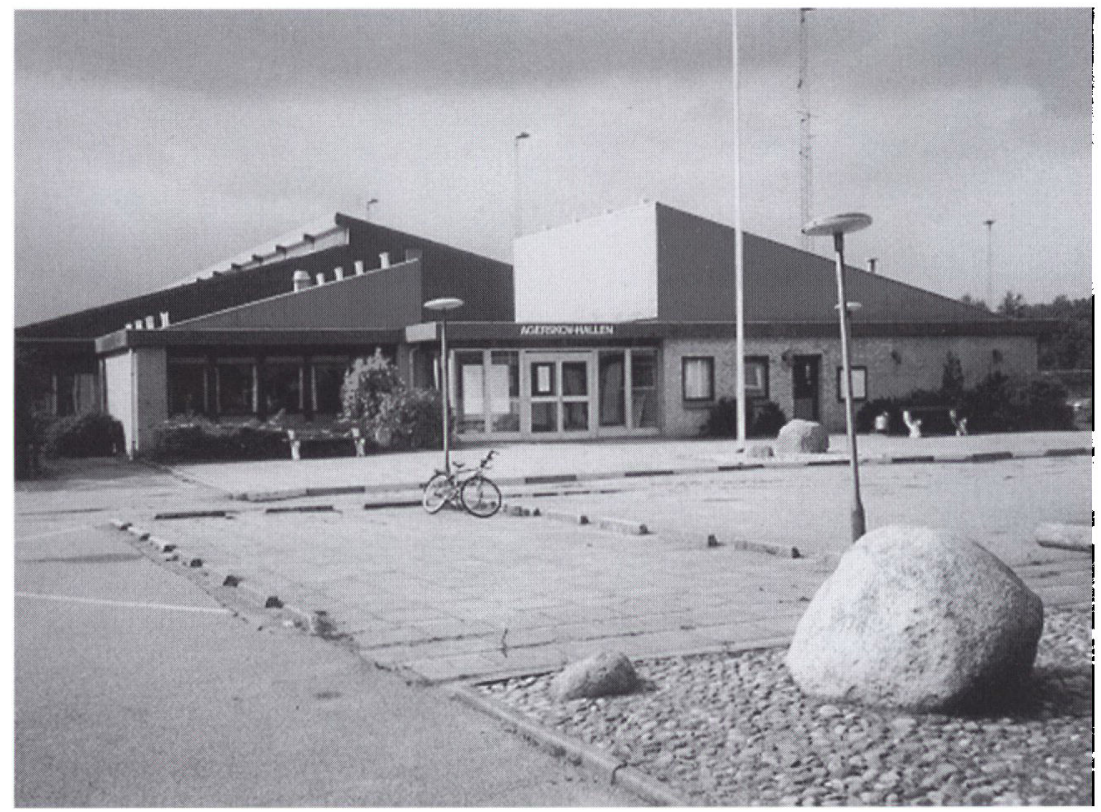

Agerskov hallen set fra skolens parkeringsplads, oktober 2000. Foto: Forfatteren.

vendigheden $\mathrm{i}$ »at gøre noget for de aktive unge, som vil dyrke sport" og skabe »et samlingssted for hele sognets befolkning ", mens murersvend Johannes Toft mente, der i flere år havde været brug for en hal, hvor "alle idrætsgrene kan samles". Det sidste blev uddybet af assistent frk. Anne B. Severin, som selv ville "gøre alt for at der kan blive en idrætshal i Agerskov «. Anne Severin havde tidligere spillet håndbold i Toftlund-hallen men udtalte, at hun "under de nuværende forhold [ikke] har lyst« ...

Selv om der er idrætshal i Toftlund, kniber det med at få plads til alle de, der gerne vil benytte hallen. Desuden er der jo også transportproblemerne og det, at der ikke er et forsamlingshus i byen. ${ }^{7}$

I samme rundspørge udtalte den kendte lokalhistoriker og på dette tidspunkt sparekassedirektør H.P. Jensen, at "vi har et meget aktivt idrætsliv i Agerskov, og derfor er det nødvendigt at vi får en idrætshal til gavn for hele sognet«. Herudover gjorde Jensen opmærksom på det vigtige $i$ at skabe et landsbymiljø, ligesom han på samme måde 
som Hans-Jørgen Thomsen understregede, at man ikke havde til hensigt at skade de lokale forsamlingshuse ...

En hal vil (...) kunne aflaste skolen betydeligt. Den vil være med til at skabe et miljø i Agerskov. Landsbymiljøet har ofte en større kulturel udbredelse end i større byer. Man kommer hinanden ved, derfor kan vi også bedre gå sammen om at skabe en ting (...) Jeg tror ikke, at en hal vil skade de bestående forsamlingshuse i sognet, dertil er formålet for udnyttelsen forskellig. Har vi hal, vokser behovet. ${ }^{8}$

Akkurat som H.P. Jensen - og da i øvrigt som lederne indenfor de store landsdækkende idrætssamvirker - udtrykte formanden for Ungdomsforeningen det håb, at selve idrætsfaciliteten ville trække flere folk til. Ligesom Hans-Jørgen Thomsen i byggeriets opstartsfase samtidigt betonede, at man ikke var ude på at konkurrere ...

Agerskov-hallen vil ikke blive en konkurrent til Toftlund-hallen. Som det er nu, er der helt afgjort behov for endnu en hal i Nørre-Rangstrup, og kommunen vil med to haller stå stærkt udadtil. Derfor vil der være brug for samarbejde (...) Trods den korte afstand mellem de to byer, har vi haft besvær med transporten til Toftlund-hallen (...) Når vi selv får en hal, vil der uden tvivl blive en endog meget stor tilgang til idræt. I dag har Agerskov ungdomsforening 13 hold tilmeldt sommerens fodboldturnering. ${ }^{9}$

\section{Halbyggeriet som en protest}

Artikler i Vestkysten november 1971 vidner dog om, at det i begyndelsen var den nævnte mangel på en gymnastiksal i forbindelse med skolen, der fra de unge Agerskov-læreres side blev fremført overfor kommunen som et hovedargument for en hal. Imidlertid antydede Hans-Jørgen Thomsen overfor pressen, at Nørre Rangstrup kommune sikkert ville prioritere en udvidelse af Toftlund skole over opførelsen af en gymnastiksal eller et halbyggeri i Agerskov. ${ }^{10}$ Også ved halpremieren 2. december 1974 havde bestyrelsesmedlemmerne givet udtryk for halbyggeriet som en nærmest demonstrativ selvorganisering, der skulle opfattes som en i hvert fald indirekte protest overfor kommunen. Således refererede Vestkystens reporter, at tidligere "var kommunen ikke rede til en udvidelse på Ágerskov skole, og så var der ikke andet for end selv at gå i gang «..11

Ved 10 års jubilæet i oktober 1985 udtalte Thomsen sig endnu mere 
bramfrit til Vestkysten om den konkurrence, der havde eksisteret mellem de siden 1970 nedlagte sognekommuner.

Efter kommunesammenlægningen frygtede borgerne i den gamle Agerskov kommune, at det var slut med nye faciliteter i Agerskov - det ville blive kommunebyen Toftlund, der fik det hele. Det gav en stærk holdning i det lille samfund, og derfor var der en meget betydelig opbakning til byggeriet af hallen. Og det blev bevist, at sammenhold giver resultater. ${ }^{12}$

I et interview med forfatteren har Thomsen anført, at dette forhold $\mathrm{i}$ en vis udstrækning er fortsat op til i dag. Artiklerne vidner dog også om, at kommunen fra begyndelsen ikke forholdt sig afvisende overfor et halbyggeri, omend man i kulturudvalget i Norre Rangstrup kommune først ønskede at foretage en undersøgelse af »behovet og opbakningen blandt befolkningen ${ }^{13}$

\section{Stiftelsen af en hal- og byggebestyrelse}

Som mange andre steder $\mathrm{i}$ landet viste der sig rent faktisk at være en meget stor opbakning bag projektet fra folk $i$ alle erhvervs- og aldersgrupper, hvilket ikke blot Vestkystens spørgerunde afslørede.

Ved det stiftende møde på Agerskov kro 29. august 1972 gav således mere end 100 borgere tilsagn om at støtte projektet økonomisk og gennem frivillig arbejdskraft. Til bestyrelsen valgtes foruden HansJørgen Thomsen konstruktør Johnie Kühnau, ingeniør Henning Mathiasen, fuldmægtig John Dithlefsen, lærer Christian Povlsen og inspektør på Agerskov Ungdomsskole, lærer Tage Hedegård Christensen. Herudover blev der valgt seks suppleanter, der automatisk sammen med bestyrelsen skulle indgå $i$ »byggeudvalget « ${ }^{14}$

Allerede fra starten var der tale om et tæat samarbejde med de kommunale institutioner. Således blev et par uger senere tillige kulturudvalgets formand, Christian Schultz, Branderup, samt gdr. Anders Clausen, Galsted, valgt som bestyrelsesmedlemmer af kommunalbestyrelsen, ligesom Kresten Appel, Rangstrup, blev udpeget af skolenævnet. ${ }^{15}$

Hvad angår selve byggeriet, var anskaffelsessummen blevet beregnet til 810.000 kr., hvoraf de 700.000 skulle gå til materialer, 75.000 til arbejdsløn til håndværkere, mens de sidste 35.000 var afsat til renter. Det var i den forbindelse planen at optage to kreditforeningslån, lige- 


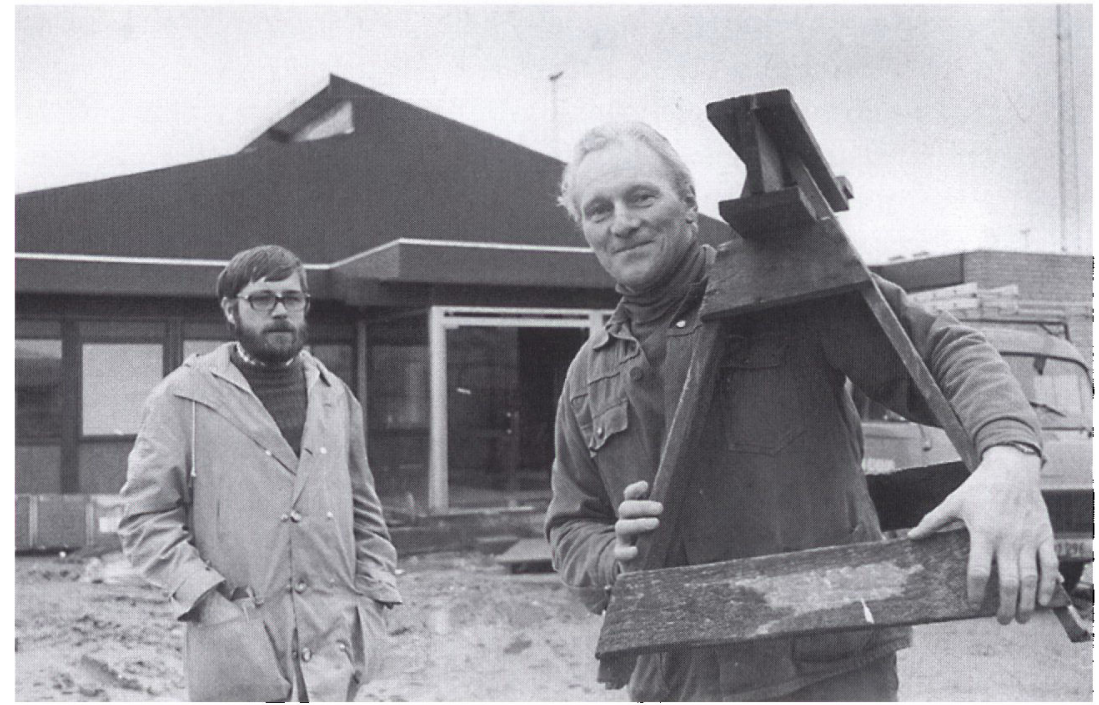

Pedel ved Agerskov skole, Laurids Mikkelsen, blev af alle udnæont som den storste slider under hele byggeperioden. I baggrunden ses konstruktor Johnie Kühnau. Foto: Vestkysten, 2. december 1974.

som man herudover håbede at opspare 150.000 gennem gaver og indsamlinger. ${ }^{16}$ Et skitseforslag til halbyggeriet var vederlagsfrit blevet udarbejdet af arkitekt Jørgen Lind, Toftlund. Der var, meddelte Vestkystens reporter, tale om "et virkelig nydeligt og enkelt projekt « med en hal på i alt 2.000 kvadratmeter. ${ }^{17}$ Det var meningen, at hallen skulle placeres på træningsbanen ved Agerskov skole. Specifikt om den frivillige arbejdskraft hed det ...

at der påregnes frivillig arbejdskraft for $200.000 \mathrm{kr}$. Da det kunne knibe at holde gejsten oppe på et vist tidspunkt af byggeriet, var der afsat $75.000 \mathrm{kr}$. til professionel arbejdsløn for at komme over et »dødt punkt ${ }^{18}$

\section{'Den gode vilje'}

Efter planlægningsfasen kom der en travl tid for Agerskov-hallens »energiske « formand Hans-Jørgen Thomsen, byggeudvalget, de omkring 450 aktive medlemmer af Agerskov Ungdomsforening, samt de omtrent hundrede andre frivillige i Agerskov og omegn. ${ }^{19}$

Der blev nu foretaget en systematisk indsamling af penge og frivil- 
ligt arbejde. Der var tale om salg af såkaldte halbeviser til $50 \mathrm{kr}$., som gav livsvarigt medlemskab af hallen. Alternativt kunne man opnå et sådant medlemskab ved at love sig til 5 frivillige arbejdstimer. ${ }^{20}$

Fra dette tidspunkt gik det stærkt med realiseringen af Agerskovhallen - et projekt, der tiltrak sig ganske stor mediebevågenhed. Således genlød det $\mathrm{i}$ januar $1973 \mathrm{i}$ Vestkysten af positive overskrifter: "De forste 5.000 kroner til Agerskov-hallen", "Nu 11.000 kroner i Agerskov «, "Nu $40.000 \mathrm{kr}$. til Agerskov-hallen " osv., indtil det slutteligt hed: "Over $80.000 \mathrm{kr}$. til Agerskovhal «. ${ }^{21}$

Rent faktisk endte resultatet med godt $100.000 \mathrm{kr}$., inklusive tilskud fra Agerskov Sparekasse samt overskud fra en halfest og nogle bankospil. ${ }^{22}$ Herudover modtog bestyrelsen et statstilskud på $25.000 \mathrm{kr}$. over Fritidsloven, 25.000 fra Mærskfonden, et beløb fra A.P. Møller Fonden, 35.000 fra det aldrig realiserede Agerskov Forsamlingshus, samt muligvis også beløb fra Tipsmidlerne, samt andre mindre, statslige tilskud. ${ }^{23}$

Ved indsamlingsrunden blev der imidlertid kun tegnet cirka 2.000 arbejdstimer, hvilket dog hovedsageligt skyldtes borgernes forsigtighed. Ved indvielsen kunne man nemlig konstatere, at det frivillige arbejde reelt havde beløbet sig til mellem 8.000 og 9.000 timer, hvilket skønnedes at være en besparelse $\mathrm{i}$ håndværkerregninger på omkring $400.000 \mathrm{kr}^{24}$

Selve byggeriet syntes at være foregået uden de store problemer, omend man 27. november 1973 i Vestkysten kunne læse følgende bøn under overskriften "Søndagsbilister " - forsynet med en opfordring til at møde op på byggepladsen søndage om morgenen og underskrevet »Agerskov-hallen«:

\footnotetext{
Søndagsbilister I må ej køre, derfor hør nu, hvad I kan gøre:

I kan hjælpe os med hallen, vær ej bange for vor kalden.

Vi vil hjælpe Jer til rette, så det eneste I bli'r er trætte.
}

I en artikel et par uger tidligere havde Hans-Jørgen Thomsen givet følgende stemningsbillede af det relativt langvarige byggeri:

Arbejdet går støt og roligt, men vi må indrømme, at de korte aftener giver mindre end beregnet, selv om vi har flyttet den ene række master 
fra fodboldbanen, således at vi har godt lys til arbejdet. Naturligvis spiller vejret også en rolle for hvor mange frivillige, der kommer og deltager $i$ arbejdet. Week-enderne giver bedst, og for det meste er der $i$ disse omkring en snes mennesker beskæftiget (...) Vi hører ganske vist ofte folk sige, at de synes, det går langsomt, men der er sandelig mange ting at tage vare på, og vi er tilfredse og optimistiske videre frem $(. . .)^{25}$

Ved årsskiftet 1974/75 begyndte man dog at kunne se en ende på »et stort og flot frivilligt stykke arbejde«, som man skrev i Vestkysten. ${ }^{26}$ Ligesom $\mathrm{i}$ forbindelse med andre halbyggerier over hele landet synes denne arbejdsproces at have skabt et stort sammenhold og en god atmosfære i hele sognet. Dette afspejler sig i Vestkystens artikler, hvor udtryk som "godt sammenhold i Agerskov sogn", "stor velvilje«, »stor hjælpsomhed « og "god vilje« går igen. ${ }^{27}$ Det er bestemt ikke tilfældigt, at den prolog, ingeniør Henning Mathiasen indledte indvielsesfesten med, netop handlede om "Den gode vilje «. ${ }^{28}$

Omend halpremieren som nævnt allerede fandt sted 2. december 1974, ønskede bestyrelsen at udsætte den officielle indvielse, idet som Thomsen udtrykte sig på bestyrelsens vegne - "[vi] ønsker, at alting skal være $\mathrm{i}$ orden, inden vi præsenterer [hallen] officielt, og desuden arbejder vi på at få et større arrangement $\mathbf{i}$ forbindelse med en indvielse $\ll .{ }^{29}$ Indvielsen fandt derfor først sted et lille års tid senere, nemlig 2. oktober 1975. Ved den lejlighed modtog halbestyrelsen i øvrigt det, der havde stået højst på dens ønskeseddel: "et væld « af pengegaver, som slutteligt beløb sig til lidt over $120.000 .^{30}$

\section{Mellem frivillighed og offentlig støtte}

Den udprægede økonomiske selvfinansiering, der prægede starten, og som beroede på energisk fundraising, kan i et nutidigt perspektiv forekomme bemærkelsesværdig - omend dette bestemt ikke var usædvanligt for et halbyggeri i første halvdel af 1970'erne. Rent faktisk blev Agerskov-hallen fra begyndelsen finansieret uden offentlig støtte overhovedet, hvis man da lige ser bort fra, at kommunen stillede en gratis grund til rådighed, samt ydede anlægsarbejder for $\mathbf{2 5 . 0 0 0}$ på pladsen foran hallen. ${ }^{31}$ Ligesom kommunen fra starten lovede at støtte hallen ved at give tilsagn om wat ville bruge den et vist antal gange gennem skolen «. ${ }^{32}$

At dette var en bevidst strategi, fremgår af selve planlægningen, finansieringen og organiseringen af projektet, samt den efterfølgende 
iver efter at nedbringe de årlige underskud gennem støttearrangementer, f.eks. halballer, banko- og lotterispil, samt ved at søge fondsmidler, modtage gaver fra lokale virksomheder, etc. ${ }^{33}$

Også flere udtalelser fra formanden Hans-Jørgen Thomsen vidner om, at i det mindste viljen til at leve op til de traditionelle principper om frivillighed og eget økonomisk ansvar prægede bestyrelsen ved afslutningen af halbyggeriet omkring nytår 1975. Ligeså tidstypisk forekommer det, at Thomsen bestemt ikke fraskrev sig en eventuel kommunal støtte, ikke mindst pga. et større budgetskred fra 810.000 i juli 1972 til over 1,1 millioner i december 1974, hovedsageligt pga. generelle prisstigninger og store renteudgifter på kreditforeningslånene. I Vestkysten 2. december 1974 lød den givetvis meget strategiske udmelding til kommunalpolitikerne derfor ...

Hans-Jørgen Thomsen slutter med håbet om, at hallen økonomisk vil kunne klare sig selv. Vi er klar over, at det bliver svært - især de første år - men forsøget vil blive gjort. Det vil være det sundeste, og det vil glæde alle, der blot har haft det mindste med byggeriet at gøre, hvis det lader sig praktisere. ${ }^{34}$

Senere samme måned på et tidspunkt, da idrætsaktiviteterne allerede var kommet godt $i$ gang, finder vi en lignende udtalelse, der vidner om et - tilsyneladende ganske frugtbart - kompromis mellem pligt til selvansvar og krav på støtte:

[Interessen] for at leje timer $\mathrm{i}$ hallen har allerede nu vist sig at være stor. - Jeg tror, at det til dels hænger sammen med, at så mange fra egnen har medvirket til, at projektet kunne gennemføres, og af erfaring ved man jo, at det man selv har været med til at skabe, hæger man om (...) - Skulle det imidlertid vise sig, at driften giver underskud, ser jeg imidlertid ikke spor forkert $i$, at kommunen træder til og støtter hallen, slutter H.J. Thomsen. ${ }^{35}$

Det er interessant at se, hvorledes det tilsyneladende ret strategiske spil mellem halbestyrelsen og kommunen udviklede sig herefter. Allerede i april 1976, da de økonomiske tømmermænd for alvor havde indfundet sig, måtte halbestyrelsen således indlede et tæet samarbejde med kulturudvalget.

I overensstemmelse med de tydeligvis landboprægede, kulturelle 'spilleregler' lød Thomsens udmelding som følger: 


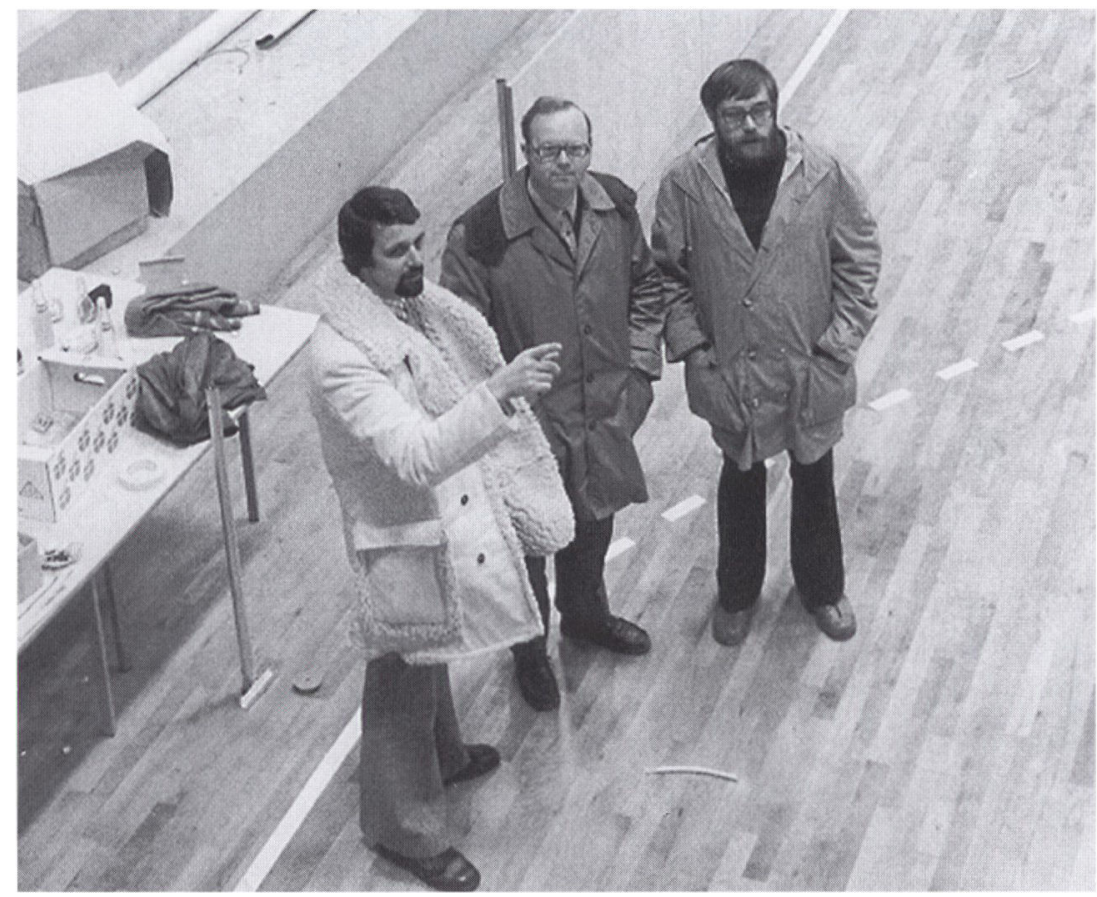

Tre af de vigtigste personer ved opforelsen af Agerskov-hallen $i$ 1973-74. Fra venstre: ingenior Henning Mathiasen, formand for halbestyrelsen lærer Hans-Jørgen Thomsen og konstruktør Johnie Kühnau. Foto: Vestkysten, 2. december 1974.

[Halbestyrelsen har] anmodet kommunens kulturudvalg om en drøftelse af problemerne. Men selvfølgelig vil vi fortsat gøre alt, hvad vi kan for at klare os selv, og vi har for nylig sendt en ansøgning til DDSG og I om et rentefrit lån på $100.000 \mathrm{kr}^{36}$

Som i forbindelse med mange andre, lignende halbyggerier i 1960'erne og første del af 1970'erne făr man en fornemmelse af, at bestyrelserne for disse selvejende institutioner hvert år måtte gå den tunge gang til kommunen for - angerfuldt og så at sige med hatten $\mathrm{i}$ hånden - at bede kommunen om at dække årets underskud.

Når man dertil lægger, at dette underskud hovedsageligt skyldtes dyre lån, inflation og stærkt forøgede udgifter til drift, vedligeholdelse, uundgåelige udvidelser o.lign. forstår man, hvorfor ansvarlige og stærkt engagerede halbestyrelsesmedlemmer undertiden kunne blive frustrerede - foreningsildsjæle med hud og hår, hvis opfindsomhed 
når det gjaldt om at skaffe penge til tider syntes nærmest ubegrænset. Et godt eksempel er f.eks. bestyrelsen for Idrætshallens Byggeforening i Fredericia i slutningen af 1950 'erne. ${ }^{37}$ Det samme kan siges om initiativtagerne til Stevns-hallen, indviet 2. november 1967. Også her var kassereren i de forste år tvunget til at gå den tunge gang til kommunen. Et daværende bestyrelsesmedlem beretter herom:

Økonomien havde det nok ikke helt godt målt med den tids målestok, og kassereren havde bekymringer, når regnskabet skulle godkendes $i$ kommunens økonomiudvalg. Ved aflæggelse af et årsregnskab kom kassereren (...) brodebetynget tilbage til bestyrelsen og fortalte, at man ved et underskud på $35.000 \mathrm{kr}$. havde meddelt ham med loftet pegefinger, at det håbede man sandeligt ikke ville gentage sig. ${ }^{38}$

På samme måde blev der set med stor bekymring på Agerskov-hallens årlige budgetunderskud i sidste halvdel af 1970'erne. Flere gange betonede Hans-Jørgen Thomsen bestyrelsens taknemmelighed, som f.eks. i marts 1975, hvor det bl.a. hed, at "uden den kommunale støtteordning kunne vi overhovedet ikke klare den med de udgifter «, hvorefter han på karakteristisk vis skyndte sig at tilføje: »Men derudover er det nødvendigt med indtægter fra banko- og støttespil foruden medlemmernes bidrag i form af kontingent « ${ }^{39}$ Eller i maj 1982 på et tidspunkt, da et årligt underskud - som man forsøgte at begrænse ved til stadighed at hæve lejeprisen, lave støttearrangementer mv. efterhånden var blevet (delvist!) acceptabelt:

Når vi kan tillade os at budgettere med et underskud, så hænger det jo sammen med, at kommunen dækker vort underskud. Derfor kan vi holde timeprisen på et nogenlunde rimeligt niveau. $O g$ jeg vil bede kommunens repræsentanter $i$ bestyrelsen om at overbringe vores tak for denne gode behandling, og de positive tanker, der ligger bag (... ${ }^{40}$

I øvrigt var også Vestkystens pressedækning tydeligvis fokuseret på den manglende økonomiske bæredygtighed, der langt op i 1980'erne prægede Nr. Rangstrup kommunes tre haller, der foruden Agerskovhallen inkluderede Toftlund-hallen, indviet oktober 1965, og Bevtofthallen, indviet 1980. Ved generalforsamlingen i Toftlund-hallen i februar 1983 angreb således formanden for kulturudvalget i Nørre Rangstrup kommune pressen for »at fremhæve idrætshallernes underskud i Nørre-Rangstrup«, mens formanden for Bevtoft-hallen, Laue Lund, i februar 1983 beklagede »de negative røster om hallens 
Annonce $i$ Vestkysten: "AgerskovHallens indsamlingsrunde». Vestkysten, 4. januar 1973.

\section{Agerskov-Hallens indsamlingsrunde}

løber fra mandag d. 15. januar til lørdag d. 27. januar!

INDSAMLINGEN SKER EFTER FØLGENDE PLAN: HVOR

Hvornår Gestrup-Gammelskov-Nitriskær mandag den 15 . januar

Bovlund-Vellerup-Bålsted tirsdag den 16 . januar

Agerskov

onsdag den 17. januar

Mellerup-Fárhus-Sindet

Rangstrupgårde-Jørgensby

torsdag den 18 . januar

Strandelhjorn-Galsted

lørdag den 20. januar

Agerskov

mandag den 22. januar

Rangstrup

tirsdag den 23. januar

Agerskov

torsdag den 25 . januar

Hvordan Alle husstande inden for samme distrikt vil blive besøgt $p \AA s$ samme aften af en lokal indsamler ifølge med et bestyrelsesmedlem.

Hvad Der kan købes halbeviser à $50 \mathrm{kr}$., som giver livsvarigt medlemsskab af halforeningen.

Der kan gives tilsagn om ydelse af et antal arbejdstimer, evt. med redskaber, under byggeriet, og endelig er kontante gaver meget velkomne.

Hvorfor for at du og dine børn og deres børn skal have et sted at være. 
regnskab ${ }^{41}{ }^{41}$ I samme forbindelse konstaterede Hans-Jørgen Thomsen i april samme år, at "vi har en sløv presse [der] kun jagter det sensationelle ${ }^{42}$

Det var dog ikke altid den generelt meget ydmyge og taknemmelige tone overfor kommunen kunne lægge en dæmper på de mere liberalistisk sindede lokalpolitikeres utålmodighed, der alle bevillinger til trods lurede lige under overfladen. Denne utålmodighed kom klart frem så sent som i maj 1989, hvor der i forbindelse med en forhøjelse af støtten til kommunens haller blev refereret følgende udtalelser fra politikerne:

Tove Schmidt $(K)$ var ikke begejstret for forhøjelsen. Hallerne er nu selvejende institutioner. Så må de være ansvarlige for deres budgetter. Princippet [om kommunale tilskud] er forkert. Det skulle ikke være nødvendigt med ekstra kommunetilskud efter nyordningen. Heller ikke to socialdemokrater var tilfredse. Erling Bertelsen mente, at hallerne nu må klare sig selv, mens Anders Kveiborg udtrykte betænkelighed ved at knytte skolernes budget sammen med hallernes. Men flertallet vedtog forhøjelsen. ${ }^{43}$

Her vidner artiklerne i Vestkysten om, at der eksisterede et vist modsætningsforhold mellem kommunens kulturudvalg, der var repræsenteret $\mathrm{i}$ halbestyrelsen og overvejende var positivt overfor støtte, og økonomiudvalget, der ønskede at begrænse støtten. ${ }^{44}$

I august 1978 modtog halbestyrelsen således et "venligt nej« til en saneringsplan, der april samme år var blevet foreslået fra bestyrelsens side som en løsning på hallens mere strukturelt betingede, økonomiske problemer, og som skulle bestå $\mathbf{i}$ »et enkelt eller to tilskud, hvorved hallens gæld kan blive bragt ud af verden - og hallen dermed kan klare sig selv «. ${ }^{45}$ »Tanken var god, men kommunens likviditet er ikke til at realisere den «, lød begrundelsen fra kommunalbestyrelsen. ${ }^{46}$ I stedet begyndte man at kræve, at Agerskov-hallen nedbragte sit underskud, hvilket da også skete, primært gennem en forhøjelse af lejeprisen. ${ }^{47}$

Heldigvis for bestyrelsen blev hallen hurtigt en stor succes, og der blev lige fra starten meldt om noget nær fuld udlejning. ${ }^{48}$ Sảledes viste det sig rent faktisk, at hallen kom til at fungere som en dynamo og magnet for det lokale idrætsliv. Ligesom vi har set det andre steder, førte opførelsen af en fællesbygning som Agerskov-hallen således til øgede medlemstal $\mathrm{i}$ idrætsforeningerne, såvel som til en øget kon- 
takt mellem beboerne. Allerede i januar 1976 kunne man læse i Vestkysten:

Agerskov-hallen har betydet et vældigt opsving for idrætten på egnen. Antallet af aktive idrætsudøvere er steget betydeligt, og $i$ håndboldafdelingen er der tale om en fordobling. Agerskov ungdomsforening har nu 550 aktive, det største antal af samtlige idrætsforeninger i kommunen. ${ }^{49}$

Bl.a. derfor kunne Hans-Jørgen Thomsen ved 10 års jubilæet i 1985 med stor tilfredshed konstatere, at "sammenhold giver resultater", og at Agerskov-hallen »er et utroligt aktiv for hele befolkningen $«{ }^{50}$ Det samme kunne siges af tusindvis af andre foreningsildsjæle rundt om $i$ landet $\mathrm{i}$ det, der måske kan betegnes som en af de vigtigste kulturelle bevægelser i Danmark i det 20. århundredes anden halvdel: »idrætshalsbevægelsen «.

\section{LITTERATUR OG KILDER}

Honoré, Peter, red. (1994) Fredericia-Hallen i 25 år. Fredericia-Hallen. M-Tryk.

Olsen, Arly (1998) "Stevnshallerne«. I: Buck, Viggo m.fl. (red.) Store Heddinge for og nu, hæfte 6, s. 73-82. Stevns Lokalhistoriske Arkiv.

Svendsen, Gunnar Lind Haase (2002) "Sognet $\mathrm{i}$ opbrud. Om æendringerne $\mathrm{i}$ det kulturelle liv på landet 1950-70 «. Magasin fra Det Kongelige Bibliotek, nr. 2, s. 35.

Svendsen, Gunnar Lind Haase (2002a) "Det store halbyggeri«. Artikel indsendt til redaktionel bedømmelse i Fortid og Nutid.

Vestkysten, 1971: 12/11, 18/11, 7/12, 17/ 12, 31/12; 1972: 30/8, 10/7; 13/9, 14/12; 1973: $4 / 1,16 / 1,17 / 1,18 / 1,26 / 1,21 / 4$, $28 / 6,10 / 11,27 / 11 ; 1974: 1 / 3,25 / 4,7 /$ 9, 23/9, 2/12, 24/12; 1975: 8/1, 24/3, 19/4, 25/9, 3/10; 1976: 10/1, 27/4, 3/8; 1977: $28 / 4,14 / 6 ; 1978: 26 / 4,31 / 4,15 /$ 8; 1979: 1/5, 27/6; 1980: 22/4; 1982: $1 /$ 5; 1983: 26/2, 23/4; 1984: 1/5; 1985: $7 /$ 10; 1988: 27/4; 1989: $1 / 5$.

Interview 28/2 2002 med skoleinspektør ved Agerskov skole Hans-Jørgen Thomsen, Agerskov.

\section{NOTER}

1. Se også Svendsen 2002, 2002a.

2. Se Svendsen 2002a.

3. Jf. interview $28 / 22002$ med skoleinspektør Hans-Jørgen Thomsen, Agerskov. Hvis andet ikke er angivet, hidrører alle citater $i$ afsnittet fra dette interview. Jeg vil gerne takke HansJorgen Thomsen for at have gennemlæst og kommenteret det frrste udkast til denne artikel.

4. Dette kan man også læse ud af artiklerne i Vestkysten, se f.eks. Vestkysten 31/12 1971.

5. Se f.eks. Hans-Jørgen Thomsen citeret i Vestkysten 31/12 1971.

6. Hans-Jørgen Thomsen citeret $i$ Vestkysten 3/10 1975. I det hele taget går ordet "samlingssted " igen. F.eks. udtrykte borgmester Ejnar Friis, Toftlund, ved indvielsen $i$ oktober 1975 et håb om, at whallen bliver det naturlige samlingssted for beboerne $i$ Agerskoz" (Vestkysten 3/10 1975).

7. Anne B. Severin citeret i Vestkysten 17/1 1973.

8. H.P. Jensen citeret i Vestkysten $17 / 1$ 1973. Thomsen udtrykte samarbejdstanken på denne måde: "Nogen mener, 
at vi vil konkurrere med Toftlund. Det er ikke tanken. Der er et behov for to haller $i$ kommunen, og vi onsker kun, at vi kan fă et godt samarbejde med Toftlundhallen og dennes bestyrelse. Vor hal skal desuden aflaste skolens gymnastiksal, og jeg tror desuden, at det vil gavne forsamlingshusene $i$ kommunen, at der bygges en hal $i$ Agerskov. Forsamlingshusene har deres miljo og publikum. De har deres programmer, men kan naturligvis ikke tage sportsarrangementer, og det er heller ikke deres formål (Hans-Jørgen Thomsen citeret i Vestkysten 17/1 1973).

9. Hans-Jørgen Thomsen citeret $i$ Vestkysten 21/4 1973.

10. Således hed det $\mathbf{i}$ Vestkysten 12 . november 1971: "Der arbejdes for tiden $i$ Agerskov for at fă en hal. Formanden for Agerskov Ungdomsforening, larer HansJorgen Thomsen, Agerskov, fortæller, at man $i$ ungdomsforeningen ved, at der er et behov for en hal, og at det ville være rimeligt, at dette behov blev dxkket. Skolen $i$ Agerskov star jo for en udvidelse, siger lærer Thomsen, og halbyggeriet kunne måske indgd sammen med udvidelsen, det er $i$ hoert fald en mulighed. Men vi er klar over, at kommunen forst og fremmest onsker at få gjort en ende på den store pladsmangel, der er på Toftlund skole, så det er ikke sikkert, at kommunen vil finansiere projektet. « Se også Vestkysten 2/12 1974 .

11. Vestkysten 2/12 1974 .

12. Hans-Jørgen Thomsen citeret i Vestkysten 7/10 1985.

13. Vestkysten $17 / 12$ og 18/11 1971 .

14. Jf. Vestkysten 30/8 1972.

15. Jf. Vestkysten 13/9 1972.

16. Jf. Vestkysten 30/8 1972.

17. Vestkysten $30 / 81972$.

18. Vestkysten 30/8 1972.

19. Den »energiske formand «: Vestkysten $17 / 11973$.

20. Vestkysten $14 / 121972$.

21. Vestkysten 16/1, 17/1, 18/1 1973.

22. Jf. Vestkysten $26 / 11973$.

23. Jf. Vestkysten $25 / 41974,19 / 41975$, 24/12 1974.

24. Jf. Vestkysten 3/10 1975.

25. Vestkysten 10/11 1973.

26. Vestkysten 7/9 1974 .

27. Se f.eks. Vestkysten $28 / 61973 ; 25 / 9$ 1975; 3/10 1975.
28. Vestkysten 3/10 1975.

29. Vestkysten 23/9 1974 .

30. Vestkysten $3 / 101975 ; 27 / 41975$.

31. Jf. Vestkysten 8/1 1975.

32. Vestkysten 10/7 1972.

33. Se f.eks. Vestkysten 24/3 1975. Meldingen fra Ungdomsforeningens Bestyrelse i marts 1975 var da heller ikke overraskende: "Selve det, at vi har fáet hallen giver store aktiviteter, og bestyrelsens opgave fremover bliver ikke sd meget at sætte noget $i$ gang som at skaffe penge til dem, der er $i$ gang " (Vestkysten 24/3 1975).

34. Vestkysten 2/12 1974.

35. Vestkysten $24 / 121974$.

36. Vestkysten $27 / 41976$.

37. Se Honoré 1994, s. 21.

38. Olsen 1998, s. 77.

39. Vestkysten $24 / 31975$.

40. Vestkysten $1 / 5$ 1982. Se f.eks. også Vestkysten 31/4 1978 og 23/4 1983. Holdningen dominerede også $i$ slutningen af 1980'erne, hvilket bestyrelsensformandens beretning i 1988 vidner om. Således referedes der bl.a.: "[Formanden] sluttede med bl.a. en tak til kommunen for at fore en god fritidspolitik. Det er dejlig, når det ikke skal ware en plage at gore et stykke frivilligt foreningsarbejde" (Vestkysten 27/4 1988).

41. Vestkysten $26 / 21983$.

42. Vestkysten 23/4 1983.

43. Vestkysten 1/5 1989.

44. I juni 1977 var der således uenighed $i$ kommunalbestyrelsen om størrelsen af driftstilskuddet til Agerskov-hallen. Kulturudvalget havde indstillet, at der i 1977 skulle ydes 130.000, mens okonomiudvalget mente, der kun burde ydes 100.000 . Førstnævnte udvalg gik i ovrigt af med sejren (Vestkysten 14/6 1977).

45. Vestkysten $31 / 4$ 1978. Se også Vestkysten 26/4 1978. Om kommunens nej, se Vestkysten 15/8 1978.

46. Vestkysten $15 / 81978$.

47. Jf. Vestkysten 1/5 1979.

48. Se f.eks. Vestkysten $3 / 81976 ; 28 / 4$ $1977 ; 27 / 6$ 1979; 22/4 1980; $1 / 5$ 1982; $1 / 51984$.

49. Vestkysten 10/1 1976.

50. Vestkysten 3/10 1985. 